\title{
Early Middle Pleistocene mammalian faunas from Kärlich and Miesenheim I and their biostratigraphical implications
}

\author{
Thijs van Kolfschoten \\ Faculteit der Pre- en Protohistorie, Rijks Universiteit Leiden, Netherlands \\ Elaine Turner \\ Forschungsbereich Altsteinzeit des Römisch-Germanisch Zentralmuseum, Mainz, Schloss \\ Monrepos, Neuwied, Germany
}

\begin{abstract}
The Kärlich and Miesenheim I localities are situated in the Neuwied Basin, in the Central Rhineland of Germany. The Pleistocene deposits in the Kärlich clay-pit have yielded several stratified faunas within which the Mimomys-Arvicola transition occurs. Based on palaeomagnetic data and heavy mineral associations, these are correlated with phases within the Dutch 'Cromerian-Complex'. The older Cromerian faunas from Kärlich indicate the presence of very high-crowned Mimomys molars; whereas in the younger faunas Anvicola is represented. Remarkable is the occurrence of Mammuthus $(M$.) trogontherii in deposits below the Matuyama/Brunhes boundary whereas Mammuthus (A.) meridionalis, a more primitive form of the Mammuthus (A.) meridionalis-Mammuthus $(M$.) trogontherii lineage has been recorded from above the Matuyama/Brunhes boundary.

The very rich fauna from Miesenheim I, a locality situated about four kilometres from the Kärlich pit, yielded further information on the faunal history of the Neuwied Basin. The assemblage with, for example, Sorex (Drepanosorex) savini, the primitive Arvicola terrestris cantiana, Canis lupus mosbachensis and Capreolus capreolus, represents an interglacial fauna correlated with the later part of the 'Cromerian Complex'.
\end{abstract}

Keywords: Middle Pleistocene Faunas; Biostratigraphy; Neuwied Basin, Germany.

\section{INTRODUCTION}

The Neuwied Basin is situated in the central part of the Rhineland (Figure 1), and was formed by a combination of uplift of the Rhenish Shield and subsidence of the Neuwied Basin area. The geomorphological history of the basin was further marked during the Quaternary period by the downcutting of the River Rhine and terrace formation, and by the deposition of loess and tephra (ashes, pumices). The tephra deposits originate from extinct volcanoes located in the neighbouring East Eifel volcanic field (Bogaard \& Schmincke 1990). The last eruption, forming the Laacher crater, took place at the end of the Weichselian at about 11,030 BP. (Hahn \& Krumsiek, in Street 1986). As a result of this eruption the Neuwied Basin was covered with a layer of pumice several metres thick.

Although Pleistocene faunas from this region were first described as long ago as the end of the nineteenth century (Schaaffhausen 1888) and were sporadically collected from several localities during the first half of this century (Günther 1907, 1910; Pohlig 1909; Hofer 1937, Mordziol 1914), the mammalian faunal record was, according to Brunnacker (1971), still too sparse to be biostratigraphically useful. The biostratigraphical potential of some remains had, however, already been noted by Nobis (1970) and Rothausen (1970). The possibility of studying a larger corpus of faunal remains has only recently been realised, mainly due to the activities of Palaeolithic archaeologists in this area (Bosinski 1992). 


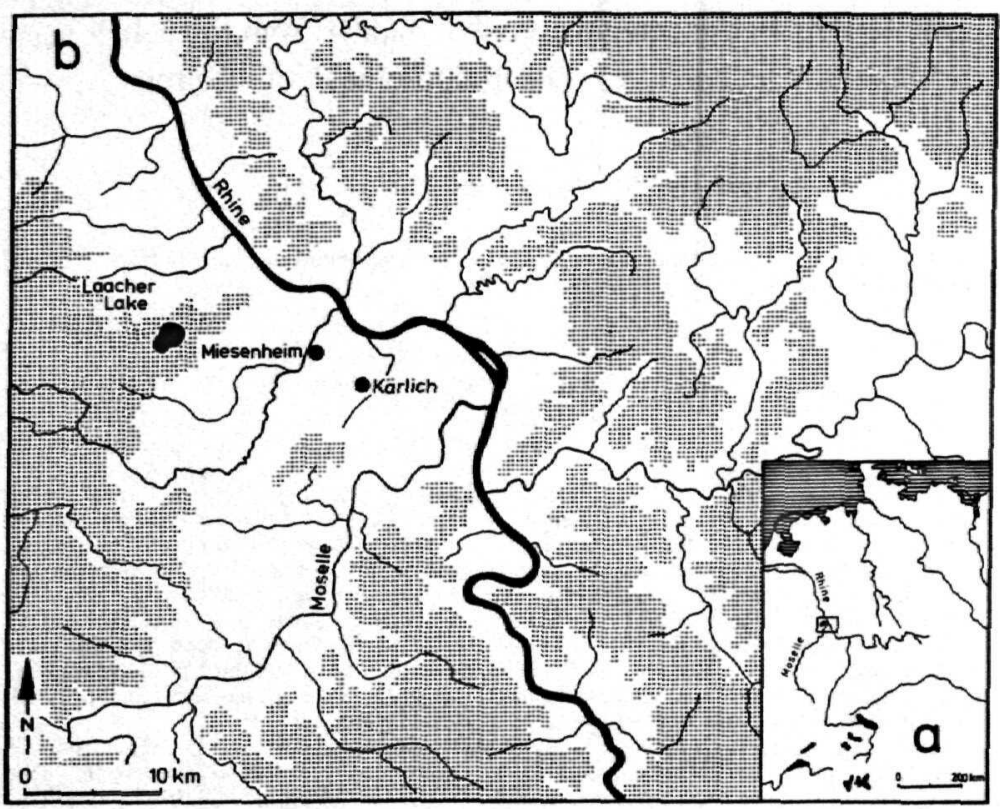

册册> $300 \mathrm{~m}$

Figure 1. The location of Kärlich and Miesenheim I;

1a: Location of the Neuwied Basin in Europe.;

1b: Situation of the localities Kärlich and Miesenheim I in the Middle Rhine area (Germany).

In 1987, an interdisciplinary research group, sponsored by the German Research Foundation, was established to investigate the "Pleistozän am Mittelrhein". The Miesenheim I and Kärlich localities have also been incorporated into this project, and scientists from several disciplines (Geologisches Institut, Köln; Institut für Palynologie und Quartärwissenschaften, Göttingen; Paläontologisches Institut, Bonn; GEOMAR, Kiel; Forschungsbereich Altsteinzeit des Römisch-Germanisches Zentralmuseum, Mainz) are currently investigating these and other sites in the area.

The aim of this paper is to present the faunas from Kärlich together with a review of the fauna from Miesenheim I and to discuss the correlation between the biostratigraphical data and the chronostratigraphical subdivision of the Middle Pleistocene. The information given in this paper is based upon the state of knowledge so far and the results should be regarded as provisional. 


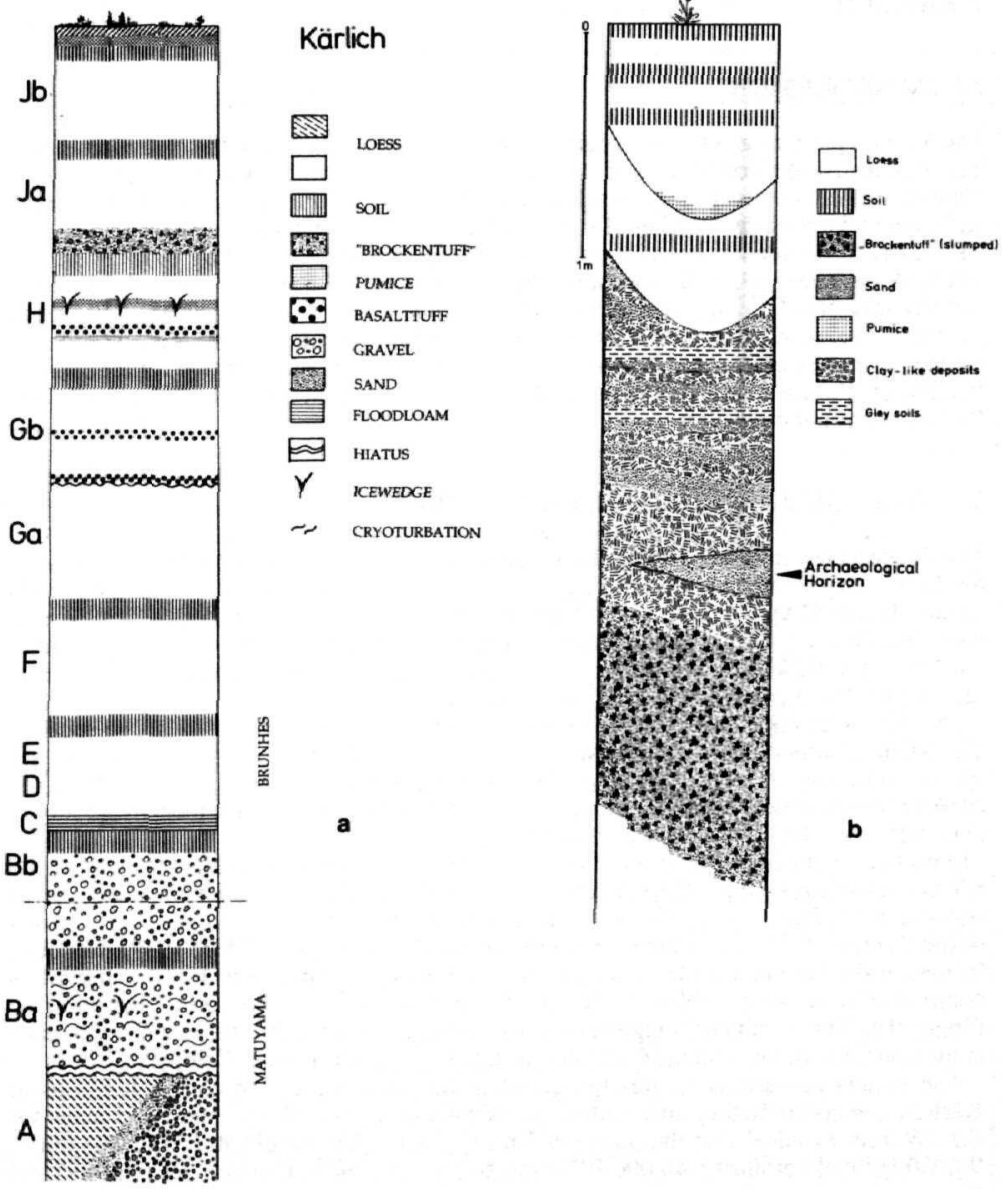

Figure 2. Schematic diagram of the sections exposed at Kärlich;

2a: The main section;

$2 \mathrm{~b}$ : The section exposed in the south-eastern part of the pit, in the area where the Kärlich "SeeUfer" site is located. 


\section{KÄRLICH}

\section{I INTRODUCTION}

The Kärlich pit, a large clay-pit located on the southwestern edge of the Neuwied Basin, has been quarried since the end of the 19th. century for its highly valuable Tertiary clay deposits. The Quaternary deposits date from the late Early Pleistocene to the Holocene and have yielded a large number of stone artefacts and larger mammalian fossils.

The Kärlich section has been investigated by many authors (e.g. Pohlig 1913; Mordziol 1914, 1952; Remy 1959; Brunnacker, Streit \& Schirmer 1969). However, the geology and stratigraphy of the sequence is still not fully understood. For instance, the correlation between the section exposed in the south-eastern corner of the pit, where the archaeological excavations are currently taking place, and the main section is problematic. In addition, the correlation between the Kärlich section and the general subdivision of the Pleistocene is not quite clear.

\subsection{GEOLOGICAL SETTING AND STRATIGRAPHY}

The Quaternary strata exposed in the Kärlich Pit overlie Tertiary deposits. The base of the Quaternary sediments consists of gravels deposited by the Rhine, followed by gravels of the Moselle River. The section on top of these gravels (Figure 2a) consists of loess or loess-like deposits alternating with ash and pumice. A number of paleosols are present in the loess-like deposits. For a more detailed description of the sequence the reader is referred to Brunnacker $(1968,1971)$ and Brunnacker et al. (1969).

Two palaeomagnetic reversals have been recognized in the lower part of the section. The Matuyama/Brunhes boundary with an age of about 730,000 years is located in Unit $\mathrm{Bb}$ (Brunnacker et al. 1976). Another palaeomagnetic reversal, which might be correlative with the Jaramillo event, has been recognized in the sediments of Unit $\mathrm{Ba}$ (Boenigk et al. 1974, Brunnacker et al. 1976).

Important changes in the heavy-mineral associations have also been recognized in the Kärlich exposures. The distinct change from sediments dominated by hornblende to sediments dominated by pyroxenes, a transition which can be traced throughout deposits in the Central and Lower Rhine region (Razi Rad 1975; Zagwijn 1985, 1989), has been located at the base of Unit H (Boenigk, personal commmmunication, 1990). Unit Gb is dominated by brown-hornblende whereas Unit $\mathrm{H}$ contains mainly pyroxenes (augite) (see Figure 10). The hornblende-augite boundary is located in the Dutch Pleistocene sequence at the transition of late Glacial C to Interglacial IV of the 'Cromerian Complex'.

The results of various studies to determine the absolute age of certain horizons at Kärlich, are contradictory and confusing. Windheuser et al. (1982) published dates for the "Wehrer Pumice" and the scoria of Unit H ("Kärlicher Brockentuff") of 283,000 $90,000 \mathrm{BP}$ and $150,000 \pm 40,000 \mathrm{BP}$ respectively. Recently, Bogaard et al. (1989) and Bogaard \& Schmincke (1990) have presented dates, using the ${ }^{40} \mathrm{Ar} /{ }^{39} \mathrm{Ar}$ single-grain laser fusion method, for a pumice horizon KAE-DT1 (= "Wehrer" Pumice I) of 612,000 $\pm 13,000 \mathrm{BP}$ (maximum age). The same method had produced dates of $452,000 \pm 8,000$ BP (KAE-DT2 = "Wehrer" Pumice II) and 396,000 $\pm 20,000$ BP for KAE-BT4 (= "Kärlicher Brockentuff"). Zöller et al. (1988) give TL dates of 232,000 $\pm 28,000$ and $222,000 \pm 25,000$ for loess directly below and $152,000 \pm 15,000$ for loess above the "Kärlicher Brockentuff". 
Table 1. The Pleistocene smaller and larger mammal faunas from Kärlich.

\begin{tabular}{|c|c|c|c|}
\hline & \multicolumn{2}{|c|}{ SMALLER MAMMALS } & LARGER MAMMALS \\
\hline $\mathrm{Ja}$ & Microtus sp. & & $\begin{array}{l}\text { Carnivora gen. sp. } \\
\text { Rhinocerotidae gen. sp. } \\
\text { Equus sp. } \\
\text { Bos sp./Bison sp. }\end{array}$ \\
\hline $\mathbf{H}$ & $\begin{array}{l}\text { Talpa sp. } \\
\text { Sciuridae gen sp. } \\
\text { Microtus arvalis/M. } \\
\text { agrestis } \\
\text { Microtus sp. } \\
\text { Apodemus sp. }\end{array}$ & & $\begin{array}{l}\text { Mammuthus trogontherii } \\
\text { Equus sp. (caballine) } \\
\text { Bos sp./Bison sp. }\end{array}$ \\
\hline $\mathrm{Gb}$ & $\begin{array}{l}\text { Talpa europaea } \\
\text { Talpa minor } \\
\text { Sorex sp. } \\
\text { Sorex (Drepanosorex) sp. } \\
\text { Lepus sp. } \\
\text { Sciuridae gen. sp. } \\
\text { Eliomys quercinus } \\
\text { Sicista sp. } \\
\text { Cricetus cricetus } \\
\text { Cricetus major }\end{array}$ & $\begin{array}{l}\text { Allocricetus bursae } \\
\text { Pliomys episcopalis } \\
\text { Clethrionomys glareolus } \\
\text { Microtus (Tericola) arvalidens } \\
\text { Microtus (Terricola) } \\
\text { gregaloides } \\
\text { Microtus anvalis/M. agrestis } \\
\text { Microtus gregalis } \\
\text { Apodemus sylvaticus' } \\
\text { Apodemus aff. maastrichtensis }\end{array}$ & $\begin{array}{l}\text { Elephantidae gen. sp. } \\
\text { Dicerorhinus sp. } \\
\text { Equus sp. (cabaline) } \\
\text { Equus sp. (primitive form) } \\
\text { Praemegaceros verticomis } \\
\text { Alces sp. } \\
\text { Cervus cf. elaphus } \\
\text { cf. Dama sp. } \\
\text { Bos sp./Bison sp. }\end{array}$ \\
\hline $\mathrm{Ga}$ & & & $\begin{array}{l}\text { Cervidae sp. indet } \\
\text { Bos sp./Bison sp. }\end{array}$ \\
\hline $\mathbf{F}$ & \begin{tabular}{|l|} 
Spermophilus sp. \\
Dicrostonyx sp. \\
Mimomys cf. savini \\
Microtus arvalis \\
Microtus sp.
\end{tabular} & & $\begin{array}{l}\text { cf. Mammuthus (A.) meridionalis } \\
\text { Equus sp. } \\
\text { Praemegaceros verticomis } \\
\text { Cervus cf. elaphus } \\
\text { Bos } \mathrm{sp} . / \text { Bison } \mathrm{sp} \text {. }\end{array}$ \\
\hline $\mathrm{E}$ & $\begin{array}{l}\text { Sorex sp. } \\
\text { Sorex (Drepanosorex) sp. } \\
\text { Talpa europaea } \\
\text { Talpa minor } \\
\text { Sciuridae gen. sp. } \\
\text { Dicrostonyx sp. } \\
\text { Pliomys episcopalis }\end{array}$ & $\begin{array}{l}\text { Clethrionomys glareolus } \\
\text { Mimomys savini } \\
\text { Mimomys sp. (small form) } \\
\text { Microtus (Terricola) } \\
\text { gregaloides } \\
\text { Microtus (Terricola) cf. hintoni } \\
\text { Microtus arvalis/M. agrestis } \\
\text { Microtus sp. }\end{array}$ & \\
\hline D & & & Elephantidae sp. indet. \\
\hline C & $\begin{array}{l}\text { Sorex cf. runtonensis } \\
\text { Talpa sp. } \\
\text { Clethrionomys glareolus } \\
\text { Mimomys sp. (small form) }\end{array}$ & $\begin{array}{l}\text { Microtus (Terricola) anvalidens } \\
\text { Microtus (Microtus) sp. } \\
\text { Apodemus sp. }\end{array}$ & \\
\hline B & Arvicolidae gen. sp. & & $\begin{array}{l}\text { cf. Mammuthus (M.) trogontherit } \\
\text { Praeovibos priscus }\end{array}$ \\
\hline A & & & Hippopotamus sp. \\
\hline
\end{tabular}




\subsection{THE FAUNAS FROM KÄRLICH (MAIN SECTION)}

Larger mammal remains from Kärlich have already been described by several authors (Pohlig 1913; Mordziol 1914; Nobis 1970; Rothausen 1970). A few smaller mammal remains from Kärlich $F$, together with material from Kärlich $G$ and $H$, have been studied and described by Heller (in Brunnacker 1971). Lozek (in Brunnacker 1971) described the molluscan faunas from Kärlich C-J.

Many of the larger mammal fossils collected at the beginning of this century are missing; the existing fossils from Kärlich have been collected by Konrad Würges (Würges coll; Mülheim-Kärlich). In Table 1, the faunal list from the Würges collection, the results of an extensive sampling programme and the revision of previously published data are all presented.

\section{Kärlich A}

Würges Coll.: A number of lower incisor fragments of hippopotamus have been recovered from this unit (Figure 3a). The fragments could not be identified to species; they may belong to Hippopotamus antiquus (=Hippopotamus major), already mentioned by Pohlig $(1909,1913)$ and described as Hippopotamus (amphibius) Germaniae POHL. Morziol (1913) mentioned an incisor, which he referred to Hippopotamus major.

\section{Kärlich Ba}

Würges Coll.: A single elephant molar fragment, probably an upper M3 (Figure 4a), shows similarities with Mammuthus (Mammuthus) trogontherii. The tooth has a hypsodonty index of about 226 (Tables 2 and 3) which is much too high for Mammuthus (Archidiskodon) meridionalis, and compares more with that of Mammuthus (M.) trogontherii (Maglio 1973).

Table 2. The mammal fauna from Miesenheim I.

\section{MIESENHEIM I}

\section{INSECTIVORA \\ Neomys cf. newtoni \\ Sorex runtonensis \\ Sorex minutus \\ Talpa europaea \\ Talpa minor \\ Desmana sp. \\ LAGOMORPHA \\ Lepus sp.}

Sorex (Drepanosorex) savini

\section{RODENTIA}

Trogontherium cuvieri

Castor fiber

Sciurus sp.

Eliomys quercinus

Muscardinus avellanarius

Sicista sp.

Cricetus major

Allocricetus bursae

Lemmus lemmus

Pliomys episcopalis

Clethrionomys glareolus

Arvicola terrestris cantiana

Microtus (Terricola) arvalidens

Microtus (Terricola) gregaloides

\author{
Microtus anvalis \\ Microtus agrestis \\ Microtus oeconomus \\ Microtus gregalis \\ Apodemus sylvaticus \\ Apodemus aff. maastrichtiensis
}

CARNIVORA

Canis lupus mosbachensis

Ursus cf. deningeri

Mustela (Putorius) putorius

Mustela nivalis

Meles sp.

\section{PROBOSCIDEA}

Mammuthus cf. trogontherii

PERISSODACTYLA

Equus sp.

Dicerorhinus etruscus cf. brachycephalus
ARTIODACTYLA
Cervus elaphus
Caprealus capreolus
Bos sp. or Bison sp. 

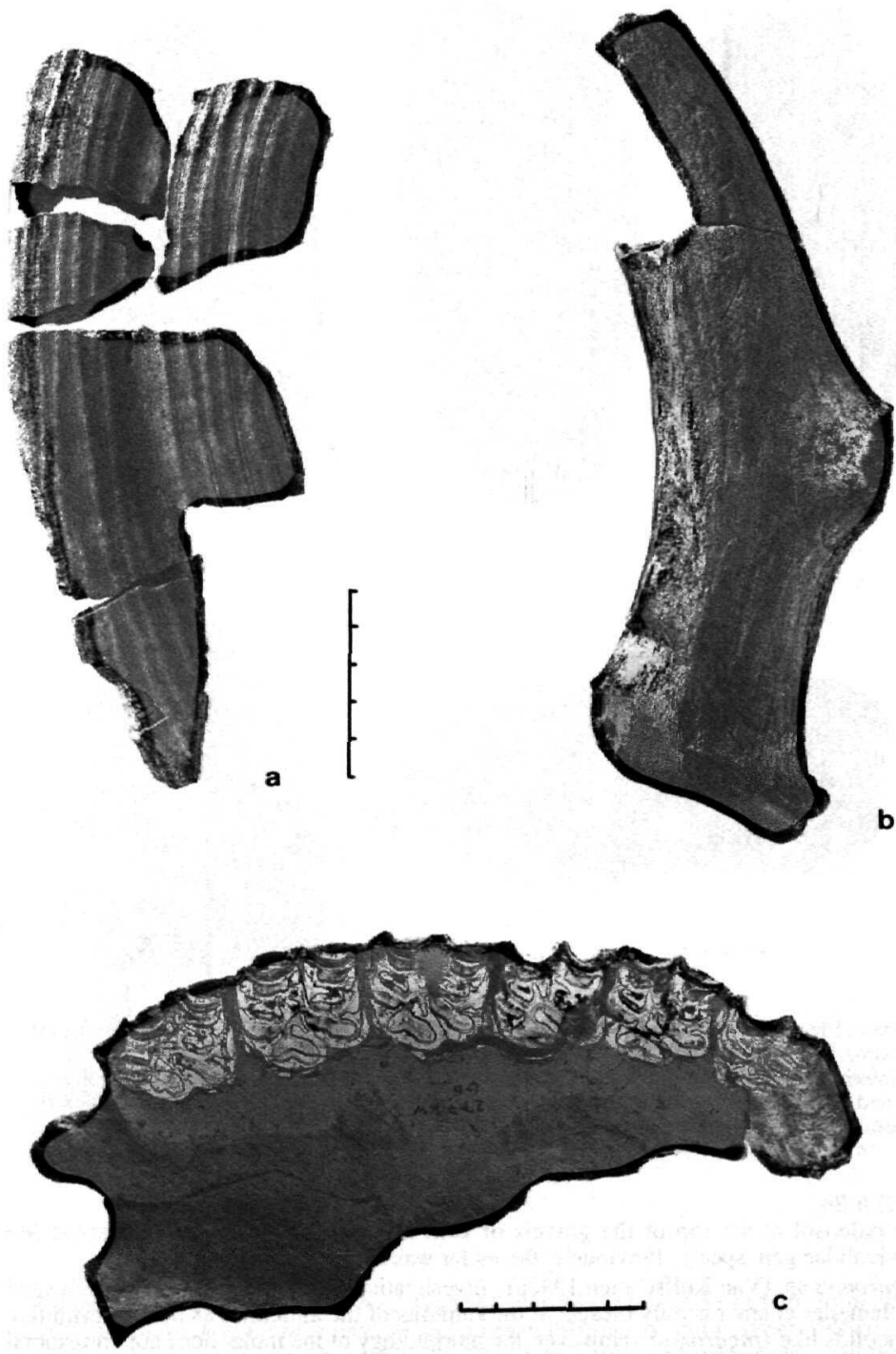

Figure 3. Larger mammal fossils from Kärlich;

3a: fragment of a canine (KW 182A) of Hippopotamus sp. from Kärlich Unit A;

3b: Shed antler base of Praemegaceros verticornis (KW F 195) from Kärlich F;

3c: complete upper cheek-tooth row (KW Gb 277) of Equus sp. from Kärlich Gb. 


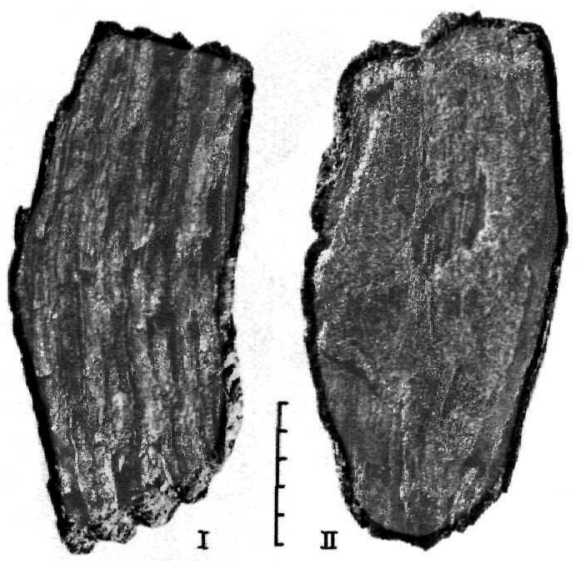

a

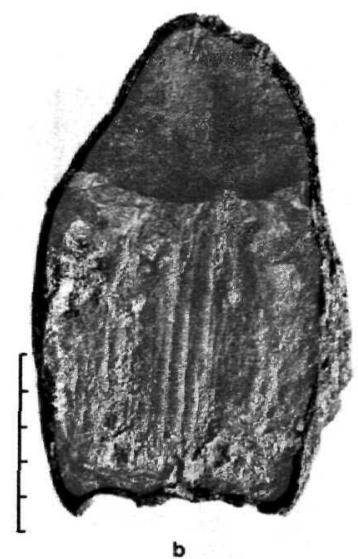

b
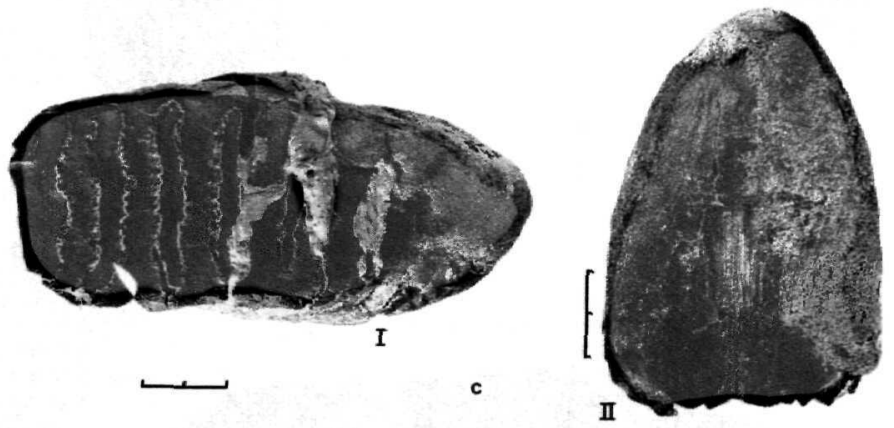

Figure 4. Elephant remains from Kärlich; 4a I and II: Upper M3 fragment of Mammuthus (M.) trogontherii (KW Ba 4) from Kärlich Ba: I: side view; II: posterior view;

$4 \mathrm{~b}$ : anterior view of lower $\mathrm{m} 3(\mathrm{KW} F \mathrm{~F}$ ) of cf. Mammuthus (A.) meridionalis from Kärlich F; 4c I and II: Upper DP4 or M1 of Mammuthus (A.) meridionalis (KW F 94) from Kärlich F: I: occlusal view; II: posterior view.

\section{Kärlich $B b$}

The paleosol at the top of the gravels of Unit Bb yielded a rooted, small sized M3 (Arvicolidae gen. spec.). Previously, the molar was assigned to and published as

Ungaromys sp. (Van Kolfschoten 1990a). Investigation of the enamel structure indicated that lamellar enamel is only present at the summits of the anticlines as in very primitive Arvicolids like Ungaromys. However, the morphology of the molar does not correspond very well with that of Ungaromys. In Pliomys, a genus which might be considered because of the morphology of the molar, the lamellar enamel extends further through the leading edges as demonstrated by Koenigswald (1980). Therefore, this molar cannot be attributed to Pliomys either (Koenigswald, personal communication, 1991). 
Table 3. Measurements of several elephant molars from Kärlich. Measurements taken according to Maglio (1973) (LF - lamellar frequency; ET - enamel thickness; HI - hypsodonty index)

\begin{tabular}{|c|c|c|c|c|c|c|c|c|c|}
\hline & KW Ba 4 & KW F 64 & $K W F 7$ & $K W F 68$ & $K W \quad F \quad 94$ & $K W F 2$ & $K W F 3$ & $K W F 99$ & KW H 121 \\
\hline ТООТн & $M^{3}$ & $\mathrm{M}_{3}$ & (?) $\mathrm{M}_{3}$ & (?) $M^{2}$ & (?) $d p^{4}$ & $d p^{4} / M^{1}$ & $d p^{4} / M^{1}$ & $d p^{4} / M^{1}$ & $M^{3}$ \\
\hline PLATES & $-4-$ & $-5-$ & -6 & -8 & 9 & 5- & 5- & $-7-$ & 13 \\
\hline WIDTH & $+93(\mathrm{IV})$ & 93.0 (1) & 104.0 (I) & $79.0(1 \mathrm{v})$ & 49.0 (II) & $52.0(\mathrm{~V} 1)$ & 57.5 (VI) & 56.0 (1) & 100.0 (VI) \\
\hline HEIGHT & $210 \cdot(I V)$ & 151 (1) & $171+$ (III) & 69.0 (VI) & $64.5+(v)$ & $51+\left(V_{1}\right)$ & $54+(V 1)$ & $79+\left(V_{1}\right)$ & $150+(\mathrm{VI})$ \\
\hline LF & 6.5 & 4.5 & 5 & 7.5 & 7 & 9 & 9 & 8.5 & $5.5-6.0$ \\
\hline ET & 2.4 & 3.0 & 3.0 & 1.75 & 1.25 & 1.2 & 1.2 & 1.5 & 2.5 \\
\hline $\mathrm{HI}$ & 226 . & 162 & $164+$ & 87 & $132+$ & 98. & 94 . & $141^{*}$ & - \\
\hline
\end{tabular}
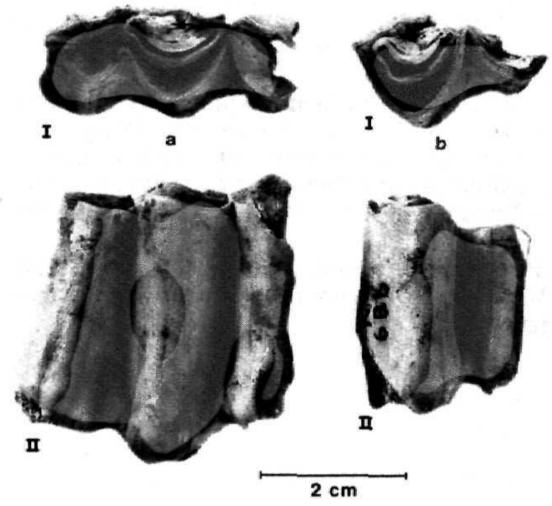

Figure 5. Praeovibos priscus from Kärlich $\mathrm{Bb}(\mathrm{KW} \mathrm{Bb} 6)$ :

5a: lower m3: above: occlusal view; below: labial view;

5 b: fragment of lower m2: above: occlusal view; below: labial view.

Würges Coll.: A partially preserved lower M2 and M3 (Figures 5a and 5b) from extinct musk ox Praeovibos priscus have been recovered from this unit (Turner 1989a). The molars are high-crowned with weakly-developed parastylid and metastylid, they lack an extostylid and the buccal valley between protoconid and hypoconid is rather deep. The crown of the lower M3 flares out towards its base, a characteristic of Praeovibos priscus (Cregut \& Guérin 1979). 


\section{Kärlich C}

The 25 identifiable smaller mammal remains collected so far from deposits of Unit $\mathrm{C}$, represent several species. The faunal assemblage is characterized by the occurrence of Sorex cf. runtonensis, Mimomys sp. (small form) and Microtus (Terricola) arvalidens (Figure 6a). The relative large number of molars of Clethrionomys glareolus $(\mathrm{N}=5)$ and the occurrence of Apodemus sp. $(\mathrm{N}=2)$ point to temperate, interglacial or interstadial, climatic conditions.

Würges Coll.: Four fragmentary vertebra were recovered from this unit. The form of the epistropheus suggests that this specimen could belong to a large bovid. An antler frontlet fragment shows the presence of a medium-sized deer (Cervidae sp. indet.) in this deposit.

The molluscan fauna with eg. Trichia hispida, Pupilla spp., Perforatella bidentata and Clausilia cf. pumila indicates a humid environment and rather cold climatic conditions. This fauna also contains redeposited fragments of interglacial species such as Ena montana and Cepaea sp. (Lozek, in Brunnacker 1971).

\section{Kärlich D}

Kärlich D-E: Würges Coll.: A skull fragment with a poorly preserved and extremely worn upper molar and part of the point of a tusk have been recorded from either Unit D or E. These remains have been referred to Elephantidae sp. indet., as a more exact identification to species could not be made.

The molluscan assemblages from Unit D with eg. Pupilla muscorum, Vallonia costata and Succinea oblonga indicate cold, glacial conditions. Samples taken at the base of Unit D contain a high percentage of redeposited fragments of interglacial species such as Azeca menkeana, Ruthenica filograna, Cepaea nemoralis, Discus rotundatus and Ena montana (Lozek in Brunnacker 1971).

\section{Kärlich $E$}

The smaller mammal assemblage from Unit $\mathrm{E}$ presented in this paper is composed of faunas collected over 20 years ago by Prof. Schirmer (Düsseldorf), Prof. Bibus (Tübingen) and Dr. Storch (Frankfurt) and samples taken recently.

The assemblage has not been studied in great detail so far. The smaller mammal assemblage (Figures $6 \mathrm{~b}-\mathrm{f} \& 7$ ) is dominated by Microtus which is represented by at least two species $M$. (T.) gregaloides (Figure 6e), and $M$. arvalis /M. agrestis (Figure 6f). Other morphotypes represented in the collection could not be identified. Characteristic for the fauna is the occurrence of high crowned molars of Mimomys savini with closed reentrant angles at their base indicating the formation of roots. One lower M1 (Figure 6b) shows the presence of roots.

Also remarkable is the occurrence of Mimomys sp., a form which differs in size from Mimomys savini. The single molar of Mimomys sp. (Figure 6d) is clearly smaller than the same element of Mimomys savini (Figure 6c). 


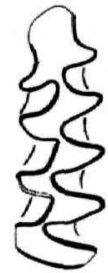

a

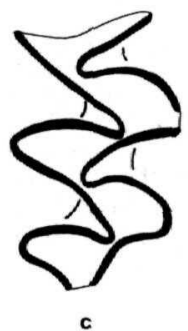

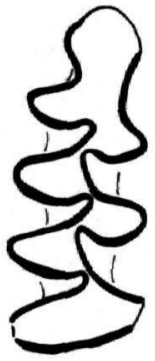

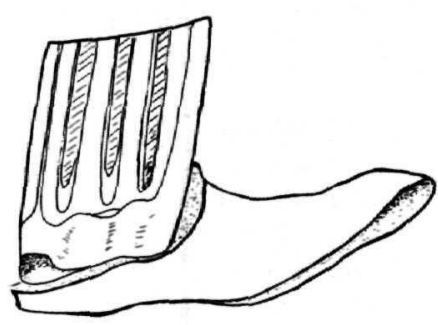

b
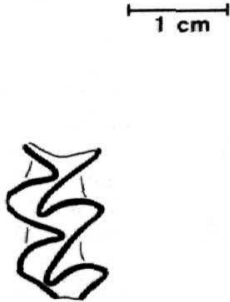

d

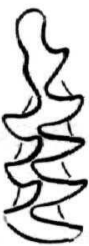

e

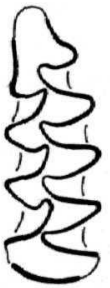

f

Figure 6. Arvicolids from Kärlich:

6a: Kärlich C: Lower ml of Microtus (Terricola) arvalidens:

6b-f: all from Kärlich E:

6b: lower, ml of Mimomys savini;

$6 \mathrm{c}$ : upper M1 of Mimomys savini;

6d: upper M1 of Mimomys sp. (small form);

Ge: lower ml of Microtus (Terricola) gregaloides;

6f: lower $\mathrm{ml}$ of Microtus (M.) arvalis or Microtus (M.) agrestis. 


\section{Kärlich E}

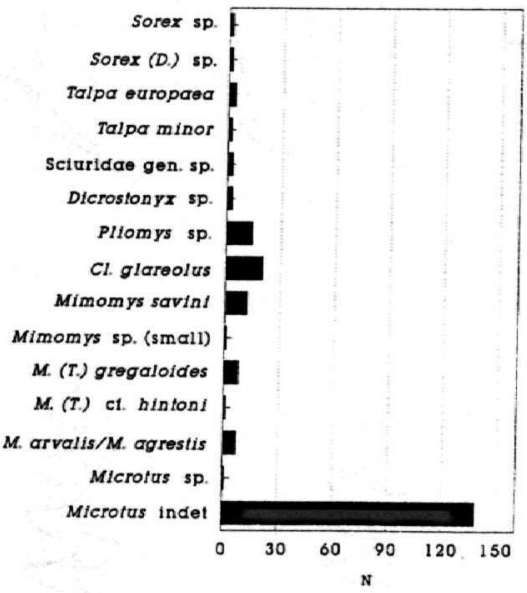

Figure 7. Composition of fauna from Kärlich E; $\mathrm{N}=$ no. of individuals.

\section{Kärlich E-F}

Nobis (1970), described a series of lower deciduous molars from one of these units and compared them, on the basis of their large size and primitive Vshaped lingual fold, with Equus sussenbornensis. Rothausen (1970) identified some poorly preserved antler fragments as Praemegaceros (=Megaloceros) cf. verticornis.

Würges Coll.: A metacarpal from horse has been identified as Equus sp. The specimen is encased for the most part in a loess concretion and therefore only a few approximate measurements could be taken. (Length: $302.00 \mathrm{~mm}$; Breadth of proximal end: $66.0 \mathrm{~mm}$; Breadth of distal end: $61.5 \mathrm{~mm}$; Breadth of diaphysys: $40.8 \mathrm{~mm}$ ). The specimen is much longer than any of the other equid metacarpals from Middle and Late Pleistocene localities in the Neuwied Basin and also exceeds the variation within metacarpals from Sussenborn and Mosbach (based on data taken from Nobis 1971) (Turner 1989a).

The mollusc assemblages from Unit E consist mainly of species such as Columella columella, Vallonia tenuilabris, Trichia hispida, Pupilla muscorum, Vallonia costata and Succinea oblonga which are characteristic of loess deposits and indicate cold glacial conditions.

The assemblages from the base of Unit E contain species such as Lymnaea sp., Planorbis planorbis, Gyraulus laevis and Valvata pulchella which indicate more humid environmental conditions. The samples from the base of Unit $\mathrm{E}$ also contain a high percentage of reworked fragments of interglacial species such as Aegopinella cf. minor, Ruthenica filograna, Cepaea nemoralis and Ena montana.

Kärlich $F$

Heller (in Brunnacker 1971) listed a number of species recorded from the loess deposits of Unit F: Microtus arvalis/M. agrestis, Microtus aff. malei resp. Microtus sp. aff. malei (=Microtus oeconomus), Microtus anglicus (=Microtus gregalis), Spermophilus (Colobotis) sp. probably aff. rufescens, Microtus cf. nivaloides (=Microtus nivalis) and Dicrostonyx sp. Almost every species is represented by only one specimen.

The assemblage collected recently from Unit $F$ is also very small and consists only of poorly preserved remains of Mimomys cf. savini, Microtus arvalis/M. agrestis and Microtus sp. Of biostratigraphical importance is the occurrence of a poorly preserved fragment of an upper molar comparable in size to Mimomys savini. The re-entrant angle base of the crown is almost closed which indicates the formation of roots, a character diagnostic of the genus Mimomys.

Species inhabiting woodland are absent in the fauna. The presence of Dicrostonyx indicates cold glacial conditions.

Würges Coll.: Several elephant molars (Figures $4 b$ and $4 c$ ) have been recovered from this unit, the measurements of which are given in Tables 2 and 3. On the basis of morphological characteristics (the widest part of the crown is towards its base), low lamellar frequency and relatively thick enamel of the M3s, these specimens are referred to 
cf. Mammuthus (Archidiskodon) meridionalis. The lower $\mathrm{m} 3 \mathrm{~s}$ in particular compare in their morphology with Mammuthus (A.) meridionalis molars from Voigtstedt (Table 3). However the hypsodonty index compares more with specimens of Mammuthus (M.) trogontherii.

A large shed antler base (Figure $3 \mathrm{~b}$ ) has been identified as belonging to extinct giant deer. The single basal tine rising about $80 \mathrm{~mm}$. behind the burr on the anterior side of the beam is characteristic of Praemegaceros verticornis.

A mandible fragment with incomplete lower cheek row and two astragali have been identified as belonging to a medium-sized cervid Cervus $\mathrm{cf}$. elaphus. The remains of horse Equus sp. and an unidentifiable large bovid Bos sp. or Bison sp. complete the fauna from this unit.

The molluscan assemblage from Unit F, listed by Lozek (in Brunnacker 1971) indicates glacial conditions during deposition of this horizon. The assemblage contains species such as Columella columella, Vallonia tenuilabris, Trichia hispida, Pupilla muscorum, Pupilla madida densegyrata, Vallonia costata, Succinea oblonga, characteristic of loess deposits. The presence of water is indicated by species such as Lymnaea stagnalis Planorbis planorbis and Sphaerium corneum.

\section{Kärlich $G$}

Heller (in Brunnacker 1971) studied three specimens available from Unit $G$ and listed two species: Clethrionomys sp., Microtus arvalis and $M$. arvalis/M. agrestis.

A much larger sample with over 2,500 identifiable specimens has been collected by processing several tons of sediment. The preliminary results of the investigation of this fauna are listed in Table 1 and also presented in Figure 9, below. The fauna is characterized by the occurrence of large, high-crowned molars which do not have roots or the beginning of root-formation. The molars are therefore assigned to Arvicola terrestris cantiana, the oldest, most primitive representative of the genus Arvicola. These primitive representatives used to be assigned to a distinct species Arvicola cantiana. However, the large variation in the modern Arvicola terrestris populations (Röttger 1987) lead to the conclusion that all the fossil NW and Central European assemblages of the genus Arvicola should be considered as belonging to a subspecies of $A$. terrestris (Kolfschoten, 1990a).

The fauna is dominated by several species of Microtus (Figure 9); Pliomys episcopalis is also rather abundant. The relative high percentage of Clethrionomys glareolus and Apodemus sylvaticus/Apodemus maastrichtiensis and the occurrence of Eliomys quercinus point to interglacial climatic conditions.

Würges Coll.: The remains of caballine horse Equus sp. and an unidentifiable cervid were recovered from Unit $\mathrm{Ga}$. A richer larger mammal fauna has been collected from Unit Gb. Remains of unidentifiable elephant, extinct rhinoceros Dicerorhinus sp., elk Alces sp., a medium-sized cervid Cervus cf. elaphus and a large, unidentifiable bovid Bos sp. or Bison sp. have been found.

Horse remains from Unit $\mathrm{Gb}$ include the complete upper cheek tooth rows and some post-cranial material from a single individual. The upper cheek teeth have primitive morphological features. The end of the inner valley of the premolars is elongated and almost touches the anterior infundibulum, a characteristic seen in the upper cheek teeth of more primitive equids such as Equus stenonis and Equus süssenbornensis. The upper molars all possess a prominent upright caballine fold extending beyound the inner valley (Figure 3c).

Two lower molars from giant deer, probably Praemegaceros verticornis and a lower $\mathrm{m} 3$ (?) from a smaller cervid, resembling fallow deer (cf. Dama sp.) in size and morphology are also present in this unit.

The molluscan assemblage from Unit G, with species such as Pupilla muscorum, Vallonia costata, Trichia hispida, Arianta arbustorum and Perforatella bidentata is characteristic of loess-deposits. The assemblage contains only a small number of species and indicates cold climatic conditions and a rather humid environment (Lozek, in Brunnacker 1971). 


\section{Kärlich $H$}

The smaller mammal assemblage, collected in the northwestern corner of the pit from a level just below the "Kärlicher Brockentuff", consists of only five identifiable specimens. The fossils belong to Talpa sp., Scriuridae gen. sp., Microtus arvalis/M. agrestis, Microtus sp. and Apodemus sp.

Würges Coll.: Amongst the larger mammal remains from this unit are two complete, but poorly-preserved upper molars of elephant. On the basis of the height/width ratio of the teeth (Table 3) and their morphological characteristics, these remains have been referred to Mammuthus $(M$.) trogontherii. A single upper molar of horse shows typical caballine characteristics such as a long protocone and caballine fold at the end of the inner valley. The remains of a large, unidentifiable bovid Bos sp. or Bison sp. have also been recovered from this unit.

The mollusc fauna from just below the "Kärlicher Brockentuff" points to full interglacial, rather humid conditions with mixed oak forest with Cepaea nemoralis, Arianta arbustorum, Cochlodina laminata, Discus rotundatus, Carychium tridentatum (Lozek, in Brunnacker 1971).

\section{Kärlich J}

An upper M3 and a fragment of a molar, both identified as Microtus sp. have been recorded from deposits just above the peat-layers of Unit $\mathbf{H}$. These deposits are preliminary assigned to Unit J.

\section{Kärlich Ja}

Würges Coll.: Larger mammal remains from this unit consist of horse Equus sp., an unidentifiable rhinoceros, already mentioned by Lanser (in Bosinski et al. 1980), a large bovid and a medium-sized unidentifiable carnivore.

The loess deposits of Unit $\mathbf{J}$ yielded a poor molluscan fauna which is dominated by Pupilla sterri. The fauna indicates glacial conditions (Lozek, in Brunnacker 1971).

\subsection{KÄRLICH "SEE-UFER" SITE}

Excavations have been undertaken in the south-eastern part of the pit since 1980 (Bosinski et al. 1980; Kröger 1990; Kulemeyer 1988; Kröger et al. 1988). Unfortunately the lack of any direct connection between the main section deposits and the sequence revealed here (Figure $2 \mathrm{~b}$ ) means that the exact stratigraphic position of the archaeological horizon is still not clear. On the presence of interglacial pollen the archaeological horizon has been referred to the "Kärlich Interglacial" as defined at this site (Bosinski et al. 1980; Urban 1983). Urban concluded that the interglacial had no clear equivalent in Northwestern Europe and must be of intra-Saalian age. Bittmann (1990) recently studied the pollen from samples taken again at the archaeological site and his results for these exposures confirmed the data published by Urban. However, he disagrees with Urban's opinion that the "Kärlich Interglacial" should be of intra-Saalian age and prefers to correlate the pollen record with a warm phase within the 'Cromerian Complex'. The pollen spectra differ in many aspects from those referred to the Holsteinian and later interglacials but correspond rather well with the Cromerian s.l. interglacials of Bilshausen and Voigtstedt (Bittmann, ibid.).

Slumped deposits of tephra ("Brockentuff") located below the archaeological horizon (Figure $2 \mathrm{~b}$ ) suggest that there is a close chronological correlation between the site and the interglacial sequence in the main section (the upper part of Unit $\mathrm{H}$ ), which is overlain by in situ deposits of 'Brockentuff".

The large mammal fauna is dominated by at least four individuals of straight-tusked elephant Elephas antiquus. Horse Equus sp., red deer Cervus elaphus, wild pig Sus scrofa and a large bovid complete the fauna. Straight-tusked elephant and wild pig are known to have occurred in faunas from interglacial deposits in association with temperate forest. At Kärlich 'See-Ufer' these species were living in more open conditions towards 
the end of an interglacial (Turner 1989a). Smaller mammals and molluscs have not been recorded from the archaeological horizon so far.

Loess deposits containing smaller mammals and molluscs were also exposed in the south-eastern corner of the pit just below the "Kärlicher Brockentuff". These deposits yielded smaller mammals and molluscs. The smaller mammal assemblage contains 94 specimens from at least 9 different species. Remarkable is the occurrence of a molar of Microtus (Terricola) cf. hintoni and two species of the genus Apodemus: Apodemus cf. sylvaticus and $A$. aff. maastrichtiensis. The composition of the fauna, together with the occurrence of Eliomys sp., indicates the presence of a wooded environment and interglacial conditions.

The molluscan fauna with eg. Clausilia pumila, Succinea oblonga, Cochlodina laminata, Acanthinula aculeata, Cepaea sp. and Carychium tridentatum points to interglacial conditions, more or less densely wooded environment and damp areas (Roth, personal communication, 1990).

\section{MIESENHEIM I}

\subsection{INTRODUCTION}

Miesenheim I is situated on a small spur of land on the eastern bank of the Nette Stream (Figure 1). The first stone artefacts and bone fragments were found here after pumice extraction in 1982, and this discovery resulted in a number of archaeological excavations between 1982-1990 (Boscheinen et al. 1984, Bosinski et al. 1988, Turner 1989b, Kolfschoten 1990a).

\subsection{STRATIGRAPHY}

The sequence at Miesenheim I (Figure 8) begins with alternating lenses of sand and loamier material upon which a weakly-developed paleeosol has formed. Above the truncated remains of this soil a colluvial horizon has formed, and during a break in this phase of sedimentation a hydromorphic soil developed. The archaeological horizon is located in the hydromorphic soil and the underlying colluvium. Stratified above the colluvial deposits is a thin pumice and immediately above this a truncated basaltic ash horizon. The mineral content and chemical composition of the pumice has shown that it is identical with the pumice KAE-DT1 in Kärlich, which has a maximum age of 618,000 $\pm 13,000$ BP (Bogaard et al. 1989, Bogaard \& Schmincke 1990). Above the tephra horizons are reworked loess deposits incorporating gravel lenses and reworked pumice and ash. The sequence is completed by a younger (truncated) ash deposit, which has so far not been identified or dated.

Recent sampling for heavy minerals at Miesenheim I shows that the whole sequence exposed at this locality is dominated by pyroxene (augites) (Boenigk, personal communication, 1990). This implies that the deposits have to be younger than the hornblende-augite boundary indicated in the Kärlich section at the base of Unit H.

Palaeobotanical data from the hydromorphic soil indicate formation of this unit towards the end of an interglacial. However, the information is too poor to allow correlation of this warm phase with any of the known Pleistocene interglacials (Urban, in Boscheinen et al. 1984).

\subsection{THE FAUNA FROM MIESENHEIM I}

The Units C-G yielded smaller mammal remains and larger mammal fossils were recorded during excavation from the Units $F$ and $G$ (Table 4). Although the mammal remains have been collected from different layers, they are regarded as one faunal unit 


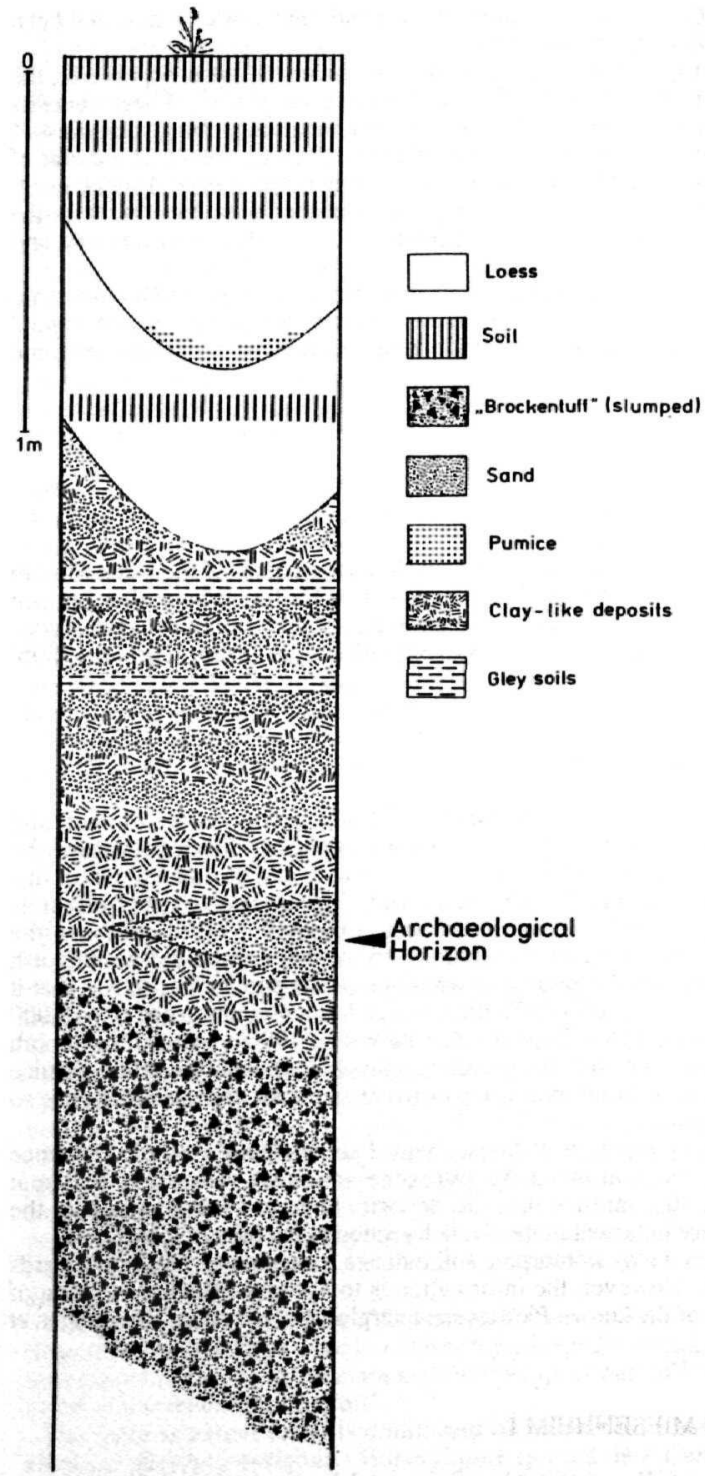

Figure 8. Simplified section through the deposits at Miesenheim I. 
Table 4. Comparison of the lamellar frequency (LF), hypsodonty index (HI) and enamel thickness (ET) of upper and lower third molars of elephant from Kärlich with those of Mammuthus (A.) meridionalis and Mammuthus (M.) trogontherii from various localities, and Mammuthus (A.) meridionalis from Voigtstedt. (1. after Maglio (1973); 2. after Dietrich (1965))

\begin{tabular}{|c|c|c|c|c|c|c|}
\hline & & KW Ba 4 & KW H 121 & M. (A.) meridionalis' & M. (M.) trogontherii ${ }^{1}$ & $\begin{array}{c}M . \text { (A.) meridionalis } \\
\text { voigtstedtiensis }\end{array}$ \\
\hline \multirow{3}{*}{$\mathrm{m}^{3}$} & LF & 6.5 & $5.5-6.0$ & $\begin{array}{r}3.7-6.1 \\
\operatorname{mean} 4.9\end{array}$ & $\begin{array}{r}5.0-8.2 \\
\text { mean } 6.5\end{array}$ & 6 \\
\hline & HI & $226+$ & - & $\begin{array}{l}93.8-152.7 \\
\text { mean } 125.6\end{array}$ & $\begin{array}{c}145.3-304.9 \\
\text { mean } 199.7\end{array}$ & $126-153$ \\
\hline & ET & 2.4 & 2.5 & $\begin{array}{r}2.6-4.1 \\
\text { mean } 3.3\end{array}$ & $\begin{array}{l}1.5-3.0 \\
\operatorname{mean} 2.2\end{array}$ & $3.5-3.7$ \\
\hline \multirow{4}{*}{$\mathrm{M}_{3}$} & & KWF 64 & $K W F 7$ & \multirow[b]{2}{*}{$\begin{array}{l}3.5-5.9 \\
\text { mean } 4.6\end{array}$} & & \multirow[b]{2}{*}{$5-6$} \\
\hline & LF & 4.5 & 5 & & $\begin{array}{l}5.0-7.2 \\
\text { mean } 6.3\end{array}$ & \\
\hline & $\mathrm{HI}$ & 162 & 164 & $\begin{array}{c}107.8-165.5 \\
\operatorname{mean} 126.4\end{array}$ & $\begin{array}{c}133.2-206.6 \\
\text { mean } 165.9\end{array}$ & 152 \\
\hline & ET & 3.0 & 3.0 & $\begin{array}{l}2.4-4.1 \\
\operatorname{mean} 3.4\end{array}$ & $\begin{array}{l}1.8-3.0 \\
\operatorname{mean} 2.3\end{array}$ & \pm 3.0 \\
\hline
\end{tabular}

because there are no phylogenetic differences between the fossils from the different layers, and the composition of the different fauna assemblages is rather uniform. Furthermore refitting together of bone fragments indicates that at least the faunas from $\mathrm{F}$ and $\mathrm{G}$ are contemporaneous.

The deposits at Miesenheim I yielded a very rich smaller mammal fauna with over 6,000 identifiable specimens. The composition of this fauna is shown in Figure 9.

None of the over 2,000 molars of Arvicola terrestris cantiana show the presence of roots or a narrowing of the re-entrant angles at the base of the crown. The Arvicola molars have the so-called Mimomys differentiation of the enamel thickness and are therefore assigned to A. terrestris cantiana, the most primitive representative of the genus Arvicola. The presence of Microtus agrestis is indicated by the occurrence of upper M2 molars with an extra postero-lingual salient angle, a character which is diagnostic for $M$. agrestis. Many lower M1 molars with a Microtus arvalis/M. agrestis morphotype have an assymetric shape typical of $M$. agrestis.

The large mammal fauna is dominated by roe deer Capreolus capreolus. Extinct wolf Canis lupus mosbachensis and extinct bear, possibly Ursus deningeri, are typical of early Middle Pleistocene/pre-Holsteinian faunas. The rhinoceros remains belong to the genus Dicerorhinus. The morphology of the post-cranial material indicates a form intermediate between $D$. e. etruscus and $D$. hemitoechus referred to $D$. e. brachycephalus by Guérin (1980).

The Units B - G yielded land and freshwater mollusca. Dominant in the assemblages of layer $\mathrm{G}$ and the lower part of $\mathrm{F}$ are the interglacial land snails Ena montana, Carychium tridentatum and Helicigona lapicida. As in the layers C - F, freshwater species indicating a stagnant, well vegetated body of water, such as Valvata pulchella, Bithynia leachi troscheli, Galba truncatula and Planorbarius corneus, represent the main part of the fauna. 


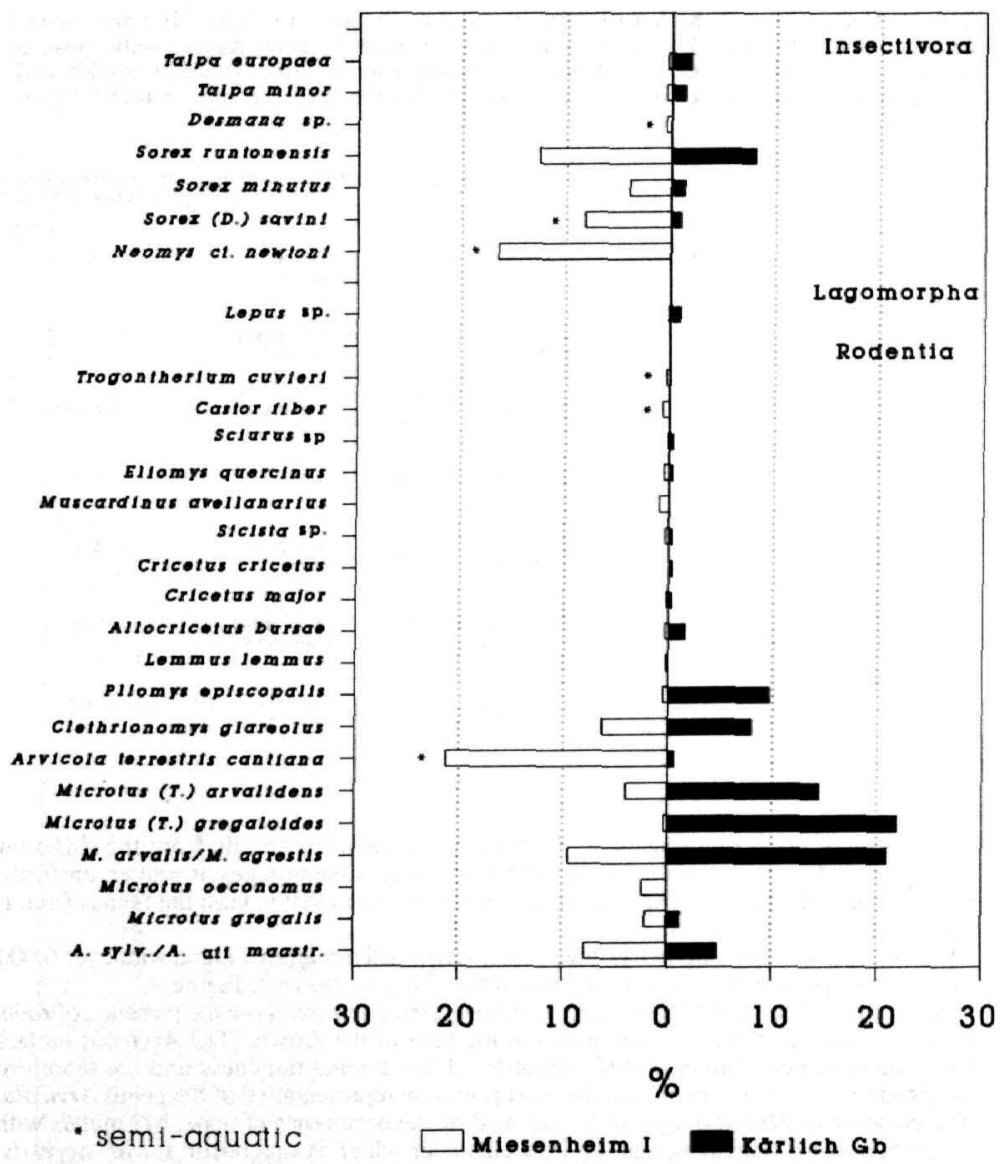

Figure 9. Composition of the fauna from Miesenheim I compared with the composition of the Kärlich Gb fauna. Both faunas are rather similar and differ mainly in composition. The fauna from Miesenheim I indicates more humid environmental conditions whereas the one from Kärlich $\mathrm{Gb}$ points to a drier climate and more open vegetation.

\subsection{PALAEOECOLOGY}

The presence of forest-dwellers such as Muscardinus avellanarius and Eliomys quercinus indicates that we are dealing with an interglacial fauna. The composition of the fauna shows wet conditions at the site itself with woodland and some open areas nearby. The molluscan fauna confirms this and indicate that the lithological Units G - B were 
deposited during the second half of an interglacial (Roth, personal communication, 1991).

Remarkable seems to be the occurrence of Lemmus lemmus. Its present distribution is restricted to arctic areas. However, Lemmus lemmus occurs in Poland in Early and Middle Pleistocene faunas which do not suggest arctic conditions but which indicate a temperate climate with the presence of forest and steppe (Kowalski 1977). Lemmus lemmus also occurs in the fauna from Petersbuch together with species indicating temperate climatic conditions and a partially wooded environment (Koenigswald 1970). According to Kowalski (1977) Lemmus lemmus has been restricted to the arctic zone only since the Late Pleistocene.

The Kärlich Gb and Miesenheim I faunas are both rich, as far as the smaller mammals are concerned. They differ mainly in composition (Figure 9). The fauna from Miesenheim I indicates more humid environmental conditions, whereas the one from Kärlich $\mathrm{Gb}$ points to a drier climate and more open vegetation.

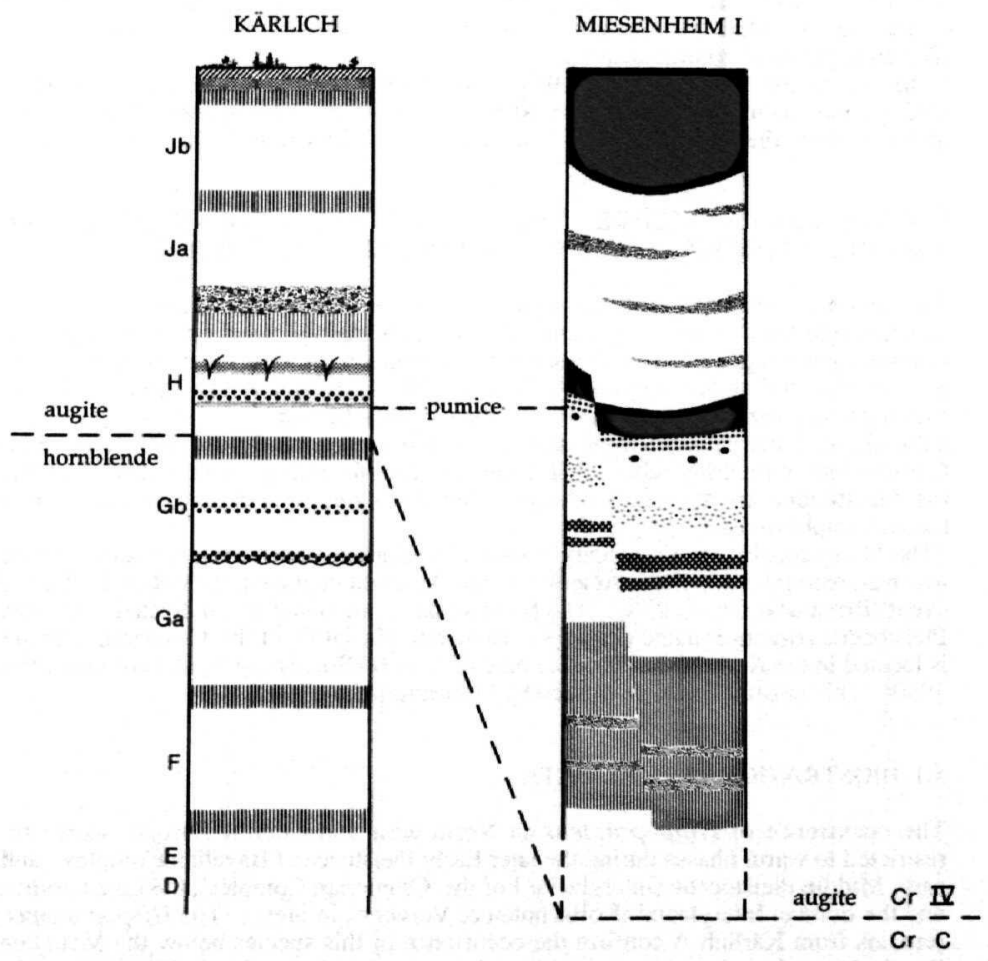

Figure 10. Correlation of the sections at Kärlich and Miesenheim I based on the dominance of the heavy minerals hornblende and augite, and the occurrence of identical tephra deposits (pumice) at both sites. 


\section{CORRELATIONS BETWEEN THE MAIN KÄRLICH SECTION AND MIESENHEIM I}

The two localities are situated only $4 \mathrm{~km}$ away from each other. The section at Miesenheim I is not as extensive as the one at Kärlich but has, nevertheless, two important correlative features (Figure 10). Firstly, the lowermost pumice bed at Miesenheim I above the fossiliferous horizon is identical with a pumice in the lower part of Kärlich Unit H (Bogaard et al. 1989, Bogaard \& Schmincke 1990). Secondly, the deposits at Miesenheim I are dominated by pyroxenes (mainly augite) which implies that the section exposed at Miesenheim I must be younger than Kärlich $\mathrm{Gb}$ and should be correlated with the oldest part of Kärlich Unit H (Figure 10). The interglacial phase, indicated at Miesenheim I by the faunal assemblages, is probably the equivalent of the phase in which the soil at the top of Unit $G$ has been formed. Therefore, it can be stated that the fauna Kärlich $\mathrm{Gb}$, collected mainly from deposits below the soil, cannot be contemporaneous with the fauna from Miesenheim I despite similarities between both faunas (Figure 9). However, this does not necessarily imply that both faunas have to be correlated to two different interglacials. Unit $\mathbf{G}$ is sedimentologically complex and it cannot be excluded that the unit represents a number of different climatic phases (Boenigk, personal communication, 1990).

The presence of ice-wedges in Kärlich Unit $\mathrm{H}$ (Figure 2a) indicate that a period with cold, glacial conditions separates the interglacial indicated at Miesenheim I and the warm phase in which the soil at the top of Unit $\mathrm{H}$ below the "Brockentuff" has been formed.

\section{CORRELATION BETWEEN THE KÄRLICH AND MIESENHEIM SECTIONS AND THE PLEISTOCENE CHRONOSTRATIGRAPHICAL SEQUENCE}

The Dutch chronostratigraphical subdivision of the Pleistocene (Table 5), taken as a standard one for Northwest and Central Europe, is mainly based on palynological and sediment-petrological data. Palynological information has only been recorded from the Kärlich 'Seeufer' archaeological site (Urban 1983, Bittmann 1988, 1990) and from the fossiliferous horizon at Miesenheim I (Urban, in Boscheinen et al. 1984). However, the palynological information from these sites is not particularly useful for correlation. Correlations of the Miesenheim I and Kärlich sections with the standard subdivision of the Pleistocene are therefore based on palaeomagnetic, sediment-petrological and biostratigraphical data.

The Matuyama/Brunhes boundary is located in Kärlich Unit $\mathrm{Bb}$ and the palaeomagnetic reversal, recognized in the sediments of Unit A, might be the equivalent of the Jaramillo event (Brunnacker et al. 1976). The hornblende-augite boundary, indicated in the Dutch Pleistocene sequence in late Glacial C - early Interglacial IV of the 'Cromerian Complex', is located in the Kärlich section at the base of Unit H (Boenigk, personal communication, 1990). This information is confirmed by biostratigraphical data.

\subsection{BIOSTRATIGRAPHICAL DATA}

The occurrence of Hippopotamus in North-west and Central Europe, seems to be restricted to warm phases during the later Early Pleistocene ('Bavelian Complex') and/or early Middle Pleistocene (Interglacial I of the 'Cromerian Complex', the Late Cromerian and the Eemian Interglacial (Kolfschoten \& Vervoort, in prep.). The Hippopotamus sp. remains from Kärlich A confirm the occurrence of this species below the Matuyama/Brunhes boundary and indicate that the palaeomagnetic fluctuation in Kärlich A might be correlative with the Jaramillo event.

The occurrence of Mammuthus (M.) trogontherii, in deposits located below the Matuyama/Brunhes boundary, indicate that there was an overlap in the stratigraphic 
Table 5. Correlation of faunas from the Neuwied Basin with the chronostratigraphical subdivision of the Pleistocene and Late Biharian and Early Toringian faunas from other localities.

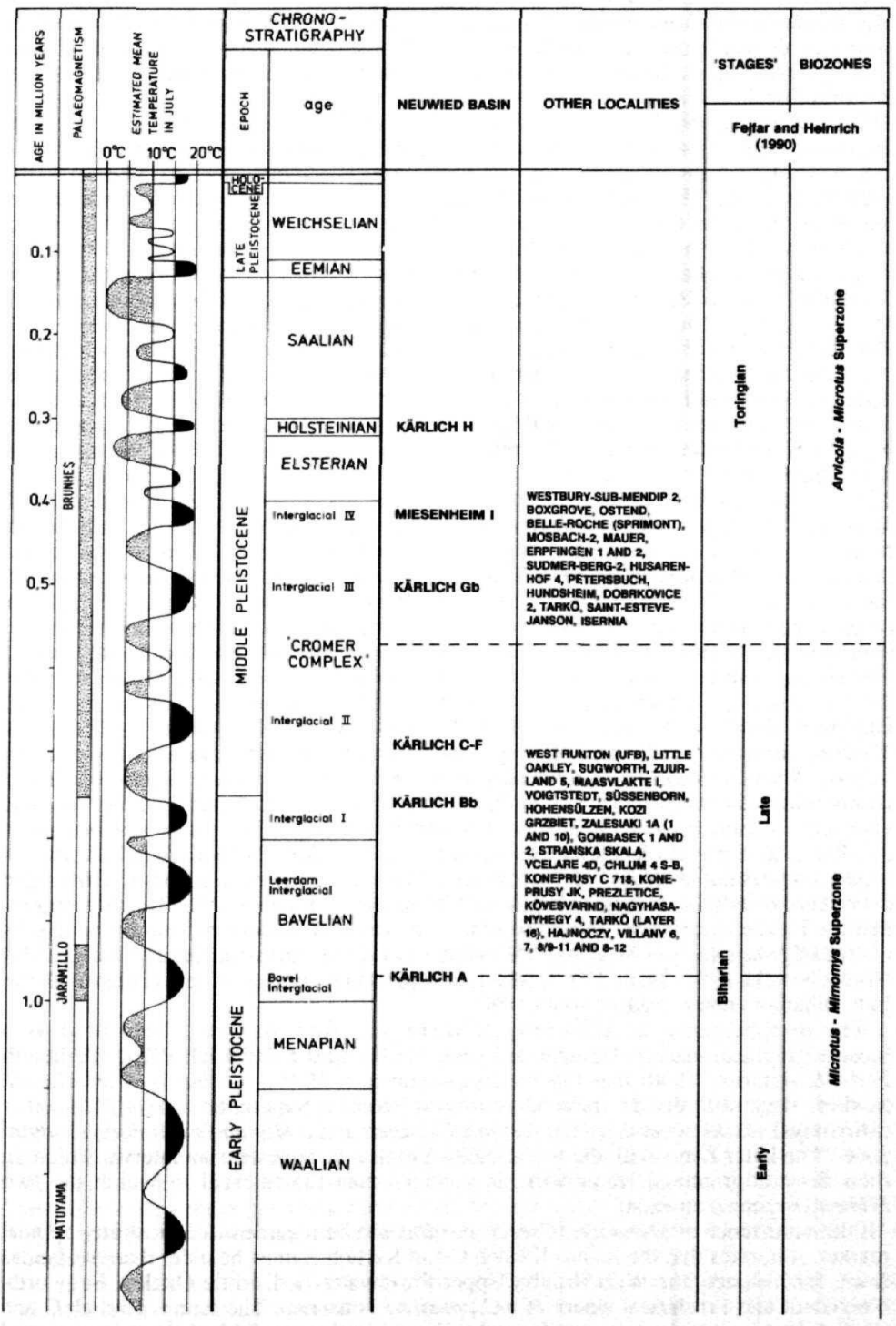


ranges of Mammuthus (A.) meridionalis and Mammuthus (M.) trogontherii. Elephant molars from Unit $\mathrm{F}$ show some similarities with those of Mammuthus (A.) meridionalis. Maybe these molars represent different ecotypes of the lineage Mammuthus (Archidiskodon) to Mammuthus (Mammuthus). The molar from Unit Ba, indicative of more steppic conditions, predates the Brunhes-Matuyama boundary and the molars from Unit $F$, representing a population indicative of a more forested environment, date to the Brunhes Epoch.

The smaller mammal faunas from Kärlich C-H and Miesenheim I are characterized by the occurrence of Microtus (Microtus) sp. and Microtus (Terricola) sp.. Microtus (Allophaiomys) is absent in these faunas. Microtus (Allophaiomys) sp. has been recently collected in Bavel (The Netherlands) from deposits dating to the Bavelian Interglacial, the oldest interglacial of the 'Bavelian Complex' (Table 5). Younger deposits from the same locality, which also date to the 'Bavelian Complex', have produced Microtus $(M$.) arvalis, a descendant of Microtus (Allophaiomys), and a very large Microtus-molar (Kolfschoten and Van der Meulen 1986; Kolfschoten 1990b). The absence of both Microtus (Allophaiomys) sp. and the large Microtus sp. in the faunas from Kärlich C-H and Miesenheim indicates that these are younger than the 'Bavelian Complex' which also supports the idea that the palaeomagnetic reversal at the top of Unit $\mathrm{Bb}$ should be correlated with the Brunhes/Matuyama boundary. The Mimomys-Arvicola boundary, which has been recorded in the Kärlich section between Unit F and Unit $\mathrm{Gb}$, predates Interglacial IV of the 'Cromerian Complex' (Kolfschoten 1990a; 1990c; Koenigswald \& Kolfschoten 1996).

The faunas from Units C, E and F at Kärlich are characterized by the co-occurrence of Mimomys savini and Microtus (Microtus) sp. and are therefore regarded as Biharian faunas (Table 5). The absence of Microtus (Allophaiomys) sp. indicates that we are dealing with Late Biharian faunas, which in turn can be correlated with a large number of faunas such as: the West Runton Upper Freshwater Bed, Little Oakley, Sugworth (England), Zuurland 5, Maasvlakte I (The Netherlands), Voigtstedt Süssenborn, Hohensülzen (Germany), Kozi Grzbiet, Zalesiaki 1A (1 and 10) (Poland), Gombasek 1, Gombasek 2, Stránská Skálá, Vcelare 4D, Chlum 4 S-B, Koneprusy C 718, Koneprusy JK, Prezletice (Czechoslovakia), Kövesvárad, Nagyharsányhesy 4, Tarkö (Layer 16), Hajnoczy, Villány 6, Villány 7, Villány 8/9-11 and Villány 8-12 (Hungary). The genus Mimomys is represented by only one species, the large Mimomys savini in most of these faunas. A smaller form, often referred to Mimomys (Cseria) pusillus, occurs only in the faunas Zuurland 5, Maasvlakte I, Hohensülzen, Zalesiaki 1A (1 and 10), Vcelare 4D, Hajnoczy, Villany 6 and 7. A smaller Mimomys form comparable in size with Mimomys pusillus is also present in the faunas Kärlich C and $E$. The fauna Kärlich $E$ is, in this aspect, comparable with the one from Hohensülzen, a locality not far from Kärlich. The occurrence of Beremendia sp. and Glis sackdillingensis (Storch et al 1973) might suggest that the Hohensülzen fauna should be older. However, Beremendia fissidence and Glis cf. sackdillingensis co-exist with Mimomys savini in the fauna from Kozi Grzbiet (Nadachowski 1985; Maul 1990), which is supposed to be one of the youngest of the Late Biharian faunas (Nadachowski 1990).

The disappearance of Mimomys (Cseria) pusillus has often been used as a biostratigraphical marker (Horacek \& Lozek 1988; Fejfar \& Heinrich 1990). Although Fejfar \& Heinrich (1990) state that the disappearance of $M$. (C.) pusillus is an insufficient marker, they still divide their Microtus-Mimomys Superzone into a Mimomys (Mimomys) savini-Mimomys (Cseria) pusillus zone and a Mimomys (Mimomys) savini zone. The latter Zone, with the type locality Voigtstedt, represents an interval which, in their biostratigraphical framework, is younger than the interval in which the two Mimomys species co-exist.

If the occurrence of Mimomys (Cseria) pusillus can be regarded as a biostratigraphical marker, it implies that the faunas Kärlich $\mathrm{C}$ and Kärlich $\mathrm{E}$ must be older than the faunas from, for instance, the West Runton Upper Freshwater Bed, Little Oakley, Sugworth, Voigtstedt and Prezletice, where $M$. (C.) pusillus is absent. The faunas Kärlich $C$ and Kärlich $\mathrm{E}$ are, as are the faunas from the Upper Freshwater Bed of West Runton and 
Voigtstedt, from deposits which are normally magnetized and correlated with the Brunhes Epoch. The earlier part of the 'Cromerian Complex', (Interglacial I of the 'Cromerian Complex' excluded) should, therefore comprise two different warm phases: an older one in which both Mimomys (Mimomys) savini as well as Mimomys (Cseria) pusillus occur and a younger phase with only Mimomys (Mimomys) savini.

However, the evolutionary stage of the Mimomys savini molars from Kärlich E, especially the height of the crown, suggests a younger age for this fauna. If this is correct, we might be dealing here with a re-immigration of a smaller Mimomys form after the "disappearance" of Mimomys (Cseria) pusillus. Another possibility is that the presence or absence of Mimomys (Cseria) pusillus is mainly due to environmental conditions. There are, however, hardly any indications for this.

A detailed study of the Microtus material might be useful in this respect. Nadachowski (1990) states that the most important difference between the fauna from Kozi Grzbiet and older faunas such as Zalesiaki $1 \mathrm{~A}$ is the occurrence at the former locality of the evolutionarily advanced Microtus ex gr. agrestis together with Mimomys savini and Microtus (Stenocranius) gregaloides.

The faunas Kärlich Gb and Miesenheim I are characterized by the absence of Mimomys and the occurrence of Arvicola terrestris (sensu Kolfschoten 1990a) together with species of the genus Microtus (Microtus). Therefore we are dealing with faunas which should be referred to the Arvicola-Microtus Superzone. This superzone corresponds with the Toringian 'Stage' defined by Fejfar \& Heinrich (1980). [It should be noted that the Toringian 'stage', as also the Villanyian and Biharian 'stages', is not a true chronostratigraphic unit, according to the rules of the International Stratigraphic Guide (Hedberg 1976). They are in fact biozones based on a concept of evolutionary stages, their boundaries remaining undefined by boundary stratotypes, as required by the rules. For this reason the term 'stage", has been placed in parentheses].

The occurrence of the most primitive representative of the genus Arvicola, Arvicola terrestris cantiana (sensu Kolfschoten 1990a) indicates that we are dealing here with Early Toringian faunas. Other early Toringian faunas are for instance: Westbury-sub-Mendip 2, Boxgrove, Ostend (England), Belle Roche (Sprimont) (Belgium), Mosbach-2, Mauer, Erpfingen 1 and 3, Sudmer-Berg-2, Husarenhof 4, Petersbuch (Germany), Hundsheim (Austria), Dobrkovice 2 (Czechoslovakia), Tarkö (Hungary), Saint-Estève-Janson (France) and Isernia (Italy). These faunas correspond with the "Arvicola Fauna Type 1" (sensu Koenigswald 1973) (Arvicola cantiana faunas containing Pliomys) and are correlated with the Arvicola terrestris cantiana -Sorex (Drepanosorex) $\mathrm{sp}$. Concurrentrange-subzone (sensu Kolfschoten 1990a).

The fauna Kärlich Gb with Arvicola terrestris cantiana has been collected from hornblende-bearing deposits predating Interglacial IV of the 'Cromerian Complex'. Hence, the fauna Kärlich Gb might be correlated with Interglacial III. This implies that the subzone, mentioned above, covers at least the upper part of the 'Cromerian Complex'. The early Toringian faunas, mentioned above and in Table 5, might therefore date to different warm phases as do the faunas Kärlich $\mathrm{Gb}$ and Miesenheim I.

\section{SUMMARY OF CONCLUSIONS}

The Kärlich and Miesenheim I sections have produced information about the faunal history during the later part of the Early Pleistocene and in particular the earlier part of the Middle Pleistocene. Remarkable is the occurrence of Mammuthus $(M$.) trogontherii in deposits below the Matuyama/Brunhes boundary, whereas Mammuthus (A.) meridionalis, a more primitive form of the Mammuthus (A.) meridionalis-Mammuthus (M.) trogontherii lineage, has been recorded from above the Matuyama/Brunhes boundary.

The Kärlich section between the Matuyama/Brunhes boundary and the 'Kärlich Brockentuff' produced a number of faunas of broadly Cromerian age. The early Cromerian mammal faunas are characterized by the occurrence of derived representatives 
of Mimomys savini. The faunas are all similar in content indicating that the sequence in which they were located was deposited fairly rapidly. This in turn could imply that the soils at the top of Units $\mathrm{E}$ and $\mathrm{F}$ do not represent two different interglacials of the 'Cromerian Complex'.

The occurrence of a smaller Mimomys form, often referred to as Mimomys pusillus, has been used as a biostratigraphical marker by many authors. The faunas Kärlich $\mathrm{C}$ and $\mathrm{E}$, in which the small form occurs, should predate faunas such as those from West Runton and Voigtstedt in which Mimomys pusillus is absent. However, the occurrence of a small Mimomys in Kärlich C and in Kärlich E together with a far derived Mimomys savini, indicate that it is questionable whether the presence or absence of a smaller Mimomys form should be used as a biostratigraphical marker. It is more likely that the occurrence of the smaller Mimomys pusillus was due to environmental factors.

More work has to be undertaken to increase our knowledge about the relative stratigraphical position of the faunas Kärlich C-Kärlich F. Palaeomagnetic data should be obtained from localities with faunas, so that more information is available about the differences between the Late Biharian faunas, that should be correlated with the Matuyama Epoch, and those which date from the Brunhes period. Furthermore new material from the Units Kärlich C - F should be investigated to provide a better sample which can be compared in detail with faunas of similar age, such as the ones from Hohensülzen, the Upper Freshwater Bed of West Runton and Voigtstedt.

The late Cromerian faunas Kärlich $\mathrm{Gb}$ and Miesenheim I are characterized by the occurrence of Arvicola terrestris cantiana. The hornblende bearing deposits of Unit Kärlich Gb produced the older Arvicola remains, which indicates that Arvicola already occurs before the hornblende-augite boundary, a stratigraphical marker horizon in the Central and Lower Rhine region which dates to the transition Glacial C - Interglacial IV of the Dutch 'Cromerian Complex'.

Whether the faunas Kärlich $\mathrm{Gb}$ and Miesenheim represent two distinct interglacials is not clear so far. A preliminary comparison between the faunas did not indicate any obvious differences. However, too little is known about the geological complexities of Unit $\mathrm{Gb}$ to be able draw detailed conclusions about the stratigraphical relationship between the fauna from the lower part of Unit $\mathrm{Gb}$ and the one from Miesenheim I, which is regarded as being the equivalent of the soil in the upper part of Unit Gb. It is important for our understanding of the faunal history during the Late Cromerian to be clear about the stratigraphical relation between the faunas Kärlich $\mathrm{Gb}$ and Miesenheim I. This knowledge would be very useful for a more detailed correlation between the chronostratigraphic subdivision and the, in some aspects rather diverse, early Toringian faunas.

The chronostratigraphical position of the 'Kärlich Interglacial' is still not clear. The correlation between the main Kärlich section and the section exposed at Miesenheim I indicates that the Kärlich $\mathrm{Gb}$, Miesenheim $\mathrm{I}$ and Kärlich $\mathrm{H}$ faunas represent three succeeding warm phases. A correlation between Miesenheim I and Interglacial IV of the 'Cromerian Complex' implies that the upper part of Unit $\mathrm{H}$ should be correlated with a younger, post-Elsterian warm phase. The Elsterian cold phase is then reflected by the ice-wedges in the lower part of Unit $\mathrm{H}$.

If the Kärlich "Seeufer" site = Kärlich Interglacial has a close chronological correlation with the interglacial sequence in the upper part of Unit $\mathbf{H}$, then the Kärlich Interglacial could have a post-Elsterian age instead of a pre-Elsterian one as Bittmann (1988, 1990; Bittmann \& Müller 1996) has suggested. The fauna from Kärlich $\mathrm{H}$ and from Kärlich "Seeufer", especially the smaller mammal record, is so far too poor to provide a contribution to the solution of this problem.

To summarize, it can be stated that the Kärlich and Miesenheim I localities contribute much information about Middle Pleistocene faunas. This information partly supports, and partly contradicts established ideas about faunal history during this period. Both sites should therefore be regarded as important reference localities for Northwest and Central Europe. 


\section{ACKNOWLEDGEMENTS}

The authors would like to express their thanks to Prof. W. Boenigk, Prof. G. Bosinski, Prof. W. von Koenigswald, Dr. K. Kröger, G. Roth, Prof. W. Schirmer, Dr. G. Storch and $M$. Street for their contributions and discussion of this paper. Our greatest thanks go to Konrad Würges for his permission to study the faunal remains in his collection. We would also like to thank P. Schiller, W. A. den Hartog and A. Hidien-Schlachter for completing the figures, and $\mathrm{G}$. Oleschinski for taking the photographs.

The study was financially supported by the Deutsche Forschungsgemeinschaft (K0$627 / 11$ ) as part of the research project "Pleistozän am Mittelrhein" .

\section{REFERENCES}

Bittmann, F. 1988. Vegetationsgeschichtliche Untersuchungen über das Pleistozän im Neuwieder Becken. Diplomarbeit des Institut für Palynologie und Quartärwissenschaften der Georg-August-Universität zu Göttingen, pp. 73.

Bittmann, F. 1990. Neue Biostratigraphische Korrelierung des Kärlicher Interglazials (Neuwieder Becken/ Mittelrhein). In W. Schirmer (ed.), Rheingeschichte zwischen Mosel und Maas. Deuqua-Führer 1, p. 67-70. Hannover: Deutsche Quartärvereinigung.

Bittmann, F. \& Müller, H. 1996. The Kärlich Interglacial site and its correlation with the Bilshausen sequence. In: Turner, C. (ed.) The early Middle Pleistocene in Europe. Rotterdam: Balkema (this volume).

Boenigk, W., Brelie, G. von der, Brunnacker, K., Koci, A., Schlickum, W. R. und Strauch, F. 1974. Zur Pliozän-Pleistozän Grenze im Bereich der Ville (Niederrheinische Bucht). Newsl. Stratigr., 3: 219-241.

Bogaard, C. van den, Bogaard, P. van den \& Schmincke, H.-U. 1989. Quartärgeologisch-tephrostratigraphische Neuaufnahme und Interpretation des Pleistozänprofils Kärlich. Eiszeitalter u. Gegenwart 39: 62-86.

Bogaard, P. van den \& Schmincke, H. -U. 1990. Die Entwicklungsgeschichte des Mittelrheinraumes und die Eruptionsgeschichte des Osteifel-Vulkanfeldes. In W. Schirmer (ed.), Rheingeschichte zwischen Mosel und Maas. Deuqua-Führer 1, p. 166-190. Hannover: Deutsche Quartärvereinigung.

Boscheinen, J., Bosinski, G., Brunnacker, K., Koch, U., Kolfschoten, T, van, Turner, E., Urban, B. 1984. Ein altpaläolithischer Fundplatz bei Miesenheim, Kreis MayenKoblenz/Neuwieder Becken. Arch. Korrbl. 14: 1-16.

Bosinski, G. 1992. Eiszeitjäger im Neuwieder Becken. Archäologie an Mittelrhein und Moselle. 3rd. Ed. Amt Koblenz der Abt. Archäologische Denkmalpflege des Landesamtes für Denkmalpflege Rheinland-Pfalz.

Bosinski, G., Brunnacker, K., Lanser, K.P., Stephan, S., Urban, B. und Würges, K. 1980. Altpaläolithische Funde von Kärlich, Kreis Mayen-Koblenz (Neuwieder Becken). Arch. Korrbl. 10: 295-314.

Bosinski, G., Kolfschoten, T. van and Turner, E. 1988. Miesenheim I, Die Zeit des Homo erectus. Andernacher Beitrage 2, pp. 56.

Brunnacker, K. 1968. Das Quartärprofil von Kärlich/Neuwieder Becken. Geologie en Mijnbouw 47: 206-208.

Brunnacker, K. 1971. Beitrage zur Stratigraphie des Quartär-Profils von Kärlich am Mittelrhein. Mainzer Naturw. Archiv 10: 77-100.

Brunnacker, K., Streit, R., \& Schirmer, W. 1969. Die Aufbau des Quartär-profils von Kärlich/Neuwieder Becken (Mittelrhein). Mainzer Naturw. Archiv 8: 102-133.

Brunnacker, K., Boenigk, W., Koci, A. \& Tillmanns, W. 1976. Die Matuyama/Brunhes-Grenze am Rhein und an der Donau. N. Jb. Geol. Palaont. Abh. 151: 358378. 
Crégut, E. \& Guérin, C. 1979. Première découverte en Europe Sud-occidentale de Praeovibos priscus (Mammalia, Artiodactyla, Ovibovinae) dans le Gisement pleistocène moyen Ante-Rissien de la Caune de L'Arago (Tautavel, Pyrenéesorientales, France). Geobios 12: 459-465.

Dietrich, W. O. 1965. Fossile Elephantenzähne von Voigtstedt in Thüringen. Palaont. $A b h$. A, II: 521-536.

Doppert, J. W. Chr., Ruegg, G. H. J., Staalduinen, C. J. van, Zagwijn, W. H. \& Zandstra, J. G. 1975. Formaties van het Kwartair en Boven-Tertiair in Nederland. In W.H. Zagwiin \& C.J. van Staalduinen (eds), Toelichting bii geologische overzichtskaarten van Nederland, p. 11-56. Haarlem: Rijks. Geol. Dienst.

Fejfar, O. \& Heinrich, W.-D. 1980. Zur biostratigraphischen Abgrenzung und Gliederung des kontinentalen Quartärs in Europa an Hand von Arvicoliden (Mammalia, Rodentia). Cas. Mineral. Geol. 25: 185 -189.

Fejfar, O. \& Heinrich, W.-D. 1990. Proposed biostratigraphical division of the European continental Neogene and Quaternary based on muroid rodents (Rodentia Mammalia). In Fejfar, O. \& Heinrich, W.-D. (eds) Int. Symp. Evol. Phyl. Biostr. Arvicolids p. 115-124. München: Pfeil.

Guérin, C. 1980. Les Rhinocerotidae (Mammalia, Perissodactyla) de Miocène supérieur au Pleistocène terminal en Europe occidentale. Comparaison avec les espèces actuelles. Thèse Doctorat d'Etat ès Sciences Univ. Lyon I, Doc. Lab. Géol. Lyon, no. 79, 3 fasc. $1185 \mathrm{pp}$.

Günther, A. 1907 Palaeolithische Fundstellen im Löß bei Coblenz. Bonner Jahrbuch 116: 345-362.

Günther, A. 1910. Zur Entstehungs- und Besiedlungsgeschichte des Neuwieder Beckens. Mannus 2, 33-57.

Hedberg, H. D. 1976. International stratigraphic guide. A guide to stratigraphic classification terminology and procedure. John Wiley \& Sons, New York, pp. 200.

Hofer, H. 1937 Fundmitteilung in Jahresbericht 1936-37. Bonner Jahrbuch 142: 275 278.

Horácek, I. \& V. Lozek 1988. Paleozoology and the Mid-European Quaternary past: scope of the approach and selected results. Rozpravy CSAV, r. MPV 98: 1-103.

Koenigswald, W. von, 1970. Mittelpleistozäne Kleinsäuger aus der Spaltenfüllung Petersbuch bei Eichstatt. Mitt. Bayer. Staatssamml. Palaont. hist. geol. 10: 407-432.

Koenigswald, W. von, 1973 Veränderungen in der Kleinsäugerfauna von Mitteleuropa zwischen Cromer und Eem (Pleistozän). Eiszeitalter und Gegenwart 23/24: 159-167.

Koenigswald, W. von, 1980. Schmelzstruktur und Morphologie in den Molaren der Arvicoliden (Rodentia). Abh.Senckenberg. Naturforsch.Ges., 539: 1-94.

Koenigswald, W. von \& Kolfschoten, T. van, 1996. The Mimomys-Arvicola boundary and the enamel thickness quotient (SDQ) of Arvicola as stratigraphic markers in the Middle Pleistocene. In: Turner, C. (ed.) The early Middle Pleistocene in Europe. Rotterdam: Balkema (this volume).

Kolfschoten, T. van, 1990a. The evolution of the mammal fauna in the Netherlands and the middle Rhine Area (Western Germany) during the late Middle Pleistocene. Meded. Rijks Geol. Dienst 43: 1-69.

Kolfschoten, T. van, 1990b. The Early Biharian Mammal Faunas from Bavel and DorstSurae. Quartärpalaontologie 8: 265-272.

Kolfschoten, T. van, 1990c. Review of the Pleistocene Arvicolid Faunas from The Netherlands. Institute of Earth Sciences. In Fejfar, O. \& Heinrich, W.-D. (eds) Int. Symp. Evol. Phyl. Biostr. Arvicolids p. 115-124. München: Pfeil.

Kolfschoten. T. van, \& van der Meulen, A.J. 1986. Villanyian and Biharian mammal faunas from The Netherlands. Mem. Soc. Geol. It. 31: 191-200.

Kowalski, K. 1977. Fossil Lemmings (Mammalia, Rodentia) from the Pliocene and Early Pleistocene of Poland. Acta Zoologica Cracoviensia XXII, 7, 297-318.

Kröger, K. 1990. Die Archäologischen Funde in der Tongrube Kärlich. In W. Schirmer (ed.) Rheingeschichte zwischen Mosel und Maas. Deuqua-Führer 1, p. 75-80. Hannover: Deutsche Quartärvereinigung. 
Kröger, K., Bittmann, F., Bogaard, P. van den \& Turner, E. 1988. Neue Ausgrabungen in Kärlich - Der Fundplatz Kärlich See-Ufer. Jahrbuch des Römisch-Germanisches Zentralmuseums Mainz 35: 111-135.

Kulemeyer, J. 1988. Die alt- und mittelpaläolithischen Funde von Kärlich. Diss. University Cologne.

Maglio, V. J. 1973. Origin and evolution of the Elephantidae. Transactions of the American Philosophical Society N.S., 63: 1-149.

Maul, L. 1990. Überblick über die unterpleistozänen Kleinsäugerfaunen Europas. Quartärpalaontologie 8: 153-191.

Mordziol, C. 1914. Geologische Wanderungen durch das Diluvium und Tertiär der Umgebung von Koblenz (Neuwieder Becken). Die Rheinlande, 5.

Mordziol, C. 1952. Geologisches von der Moselmündung. Beitr. z. Rheinkde. 4: 17-24.

Nadachowski, A. 1985. Biharian voles (Arvicolidae, Rodentia, Mammalia) from Kozi Grzbiet (Central Poland). Acta Zool. Cracov. 29: 13-28.

Nadachowski, A. 1990. Lower Pleistocene Rodents of Poland: Faunal Succession and Biostratigraphy. Quartärpalaontologie 8: 215-223.

Nobis, G. 1970. Equiden aus dem Löss von Kärlich (Neuwieder Becken) Mz. Naturw. Arch. 9: 297-302.

Pohlig, H. 1913. L'étage à "Elephas trogontherii" sur le Bas-Rhine. Bull. Soc. Géol. Belgique 27: 142-147.

Razi Rad, M. 1975. Schwermineraluntersuchungen zur Quartärstratigraphie am Mittelrhein. Thesis Univ. Köln, pp. 164.

Remy, H. 1959. Zur Gliederung des Lösses bei Kärlich und Bröhl am unteren Mittelrhein mit besonderer Berücksichtigung der Faunen. Fortschr. Geol. Rheinl. $u$. Westf. 4: 323-330.

Rothausen, K. 1970. Praemegaceros PORTIS, 1920 (Cervidae, Mammalia) als wichtiger stratigraphischer Beleg im Quartär von Kärlich (Neuwieder Becken, Mittelrhein). Mainzer naturw. Archiv 9: 303-317.

Röttger, U. 1987. Schmelzbandbreiten an Molaren von Schermäusen (Arvicola Lacépède, 1799). Bonn. zool. Beitr. 38: 95- 105.

Schaaffhausen, H. 1888. Die vorgeschichtliche Ansiedelung in Andernach. Bonner Jahrb. 86:1-41.

Storch, G., Franzen, J. L. \& Malec, F. 1973. Die altpleistozäne Säugerfauna (Mammalia) von Hohensülzen bei Worms. Senckenbergiana lethaea 54: 311-343.

Street, M. 1986. Ein Wald der Allerödzeit bei Miesenheim, Stadt Andernach (Neuwieder Becken). Arch. Korrbl. 16: 13-22.

Turner, E. 1989a. Middle and Late Pleistocene Macrofaunas of the Neuwied Basin Region (Rhineland - Palatinate) of West Germany. Diss. University of Birmingham, pp. 480.

Turner, E. 1989b. Miesenheim I: A lower Palaeolithic site in the Middle Rhineland (Neuwied Basin), FRG. Ethnogr.-Archäol. Z. 30: 521-531.

Urban, B. 1983. Biostratigraphic correlation of the Kärlich Interglacial, Northwestern Germany. Boreas 12: 83-90.

Windheuser, H., Meyer, W. und Brunnacker, K. 1982. Verbreitung, Zeitstellung und Ursachen des quartären Vulkanismus in der Osteifel. Zeitschr. fur Geomorphologie N. F. Suppl. Bd. 42: 177-194.

Zagwiin, W. H. 1985. An outline of the Quaternary stratigraphy of the Netherlands. Geologie en Mijnbouw 64: 17-24.

Zagwijn, W. H. 1989. The Netherlands during the Tertiary and the Quaternary: A case history of Coastal Lowland evolution. Geologie en Mijnbouw 68: 107-120.

Zöller, L., Stremme H. \& Wagner G.A. 1988. Thermoluminisenz-Datierung an LössPaläoboden-Sequenzen von Nieder-, Mittel- und Oberrhein/Bundesrepublik Deutschland. Chemical Geol. (Isotope Geosc. Section) 73: 39-62. 